\title{
Effective Mechanisms of Service Outsourcing Talents Training for School-enterprise Cooperation
}

\author{
W.X.XUE \& Y.L.PEI \& D.D.LI \\ College of Management, Beijing Union University, Beijing, China
}

\begin{abstract}
With the rapid development of service outsourcing industry, service outsourcing has become a new economic growth engine of industrial restructuring and promoting. Beijing Union University (BUU), assumes the service outsourcing talents training model innovation and reform project, and actively explores outsourcing talent training mechanism. Based on the current situation of service outsourcing talents training of BUU, we propose building ideas and construction content of service outsourcing talents mechanism, which is based on school-enterprise cooperation and joint training service. Then the practice of more than three years of exploration are analyzed and summarized.
\end{abstract}

KEYWORD: School-enterprise Cooperation; Service Outsourcing; Effective Mechanism

\section{CONNOTATION OF SCHOOL-ENTERPRISE COOPERATION}

Broad variety of school-enterprise cooperation refers to cooperation activities in the areas such as talents training, scientific research and technical services in between educational institutions and industry[1]. Cooperation defined by the World Education Association in 2001 is "Cooperative Education will combine the learning in the classroom and in the work together. The students will apply theoretical knowledge in their work which is associated and get the actual remuneration with them. And then they bring the problems back to school, in order to promote school teaching and learning." In order to facilitate the evaluation and management, we can refer six evaluation criteria in 1979 Cooperative Education of Canada: (1) the working position which is developed and identified by the school is appropriate for learning; (2) cooperative education students are engaged in the actual work and not just observation; (3) cooperative education students have paid jobs; (4) students progress at work are supervised by the school; (5) the employers manage and evaluate the performance of the work; (6) total work practices account for $50 \%$ of academic learning time, the minimum is not less than $30 \%$.

\section{TALENTS TRAINING OF SERVICE OUTSOURCING}

With national attention on the development of service outsourcing industry, service outsourcing industry has a huge space of development, service outsourcing industry is also becoming an important employment direction of university students. In order to implement the spirit of "National long-term Education Reform and Development Plan (2010 2020)"[2], and the implementation of "the Ministry of Education, Ministry of Commerce, the Opinions on Accelerating Service Outsourcing talents training, promoting employment of college graduates to work", how to develop good Service Outsourcing talents is becoming a very urgent task.

There are three main training methods of service outsourcing personnel training: traditional method, training institutions or directed entrusted training, professional training[3]. Implementation and training program for each major problem faced, as shown in Table 1.

\section{THE SITUATION OF ENTERPRISE COOPERATION OUTSOURCING TALENTS TRAINING IN BEIJING UNION UNIVERSITY}

In 2009, BUU applied a project of national service outsourcing talents training innovation test area successfully. Most teachers do not have experience in service outsourcing talent training, the young teachers are most of PhD students who are just graduated. So college of management school will service outsourcing talents positioned as colleges and enterprises training together. in BUU enterprise cooperation is positioned to Training Program of service outsourcing talents. 
Table 1. Mode of service outsourcing talent training

\begin{tabular}{|c|l|l|l|}
\hline No. & Mode & Implementation & Main problem \\
\hline 1 & traditional method & $\begin{array}{l}\text { Enterprises as the main do the in-house training } \\
\text { for new employees, develop their practical project } \\
\text { development and writing skills in a team mode }\end{array}$ & Increase the burden of enterprises \\
\hline 2 & $\begin{array}{l}\text { training institutions or } \\
\text { directed entrusted } \\
\text { training }\end{array}$ & $\begin{array}{l}\text { Training institutions emphasis on practical skills } \\
\text { training, post-training students to enter the job } \\
\text { role faster }\end{array}$ & $\begin{array}{l}\text { Charge of training institutions to attract the } \\
\text { best students less }\end{array}$ \\
\hline 3 & professional training & $\begin{array}{l}\text { Specialized training, basic professional } \\
\text { development theory }\end{array}$ & $\begin{array}{l}\text { Practicing technology is lagging behind, } \\
\text { lack of practical experience in development, } \\
\text { project communication and teamwork } \\
\text { exercises, they must be post-training }\end{array}$ \\
\hline
\end{tabular}

\subsection{Set up a union of school-enterprise cooperation}

Under the leadership of the BUU leaders we sign a number of service outsourcing enterprises and establish partnership very well. The enterprises which we choose are large-scale, mutual benefit and industry characteristic. In the course of the schoolenterprise cooperation, we not only go out of school but also attract the businesses to school. Teachers lead students to the enterprise, recommend jobs for excellent students. At the same time, we employ teachers who are working in company to make vocational training. School of management is in charge of researching on BPO service outsourcing. In 2013 June, we convened more than 40 small and medium enterprises formed School - Enterprise Cooperation Union. Such as China Financial Computerization Corporation Finance Division, Beijing Golden Elephant Online Network Technology Co., Ltd., Beijing Dong Lu Culture Communication Co., Ltd., Beijing Qiu Chunhua Culture Communication Co., Beilangzhong agriculture, industry groups, in limited Yat accountant firm company. etc. Some of them are service outsourcing enterprises, Bo Yan Technology Co., Ltd., Shanghai Business School Network Technology Co., Ltd., Beijing Information Technology Co., Ltd. Li Masato, eight hundred passengers (Beijing) Software Technologies Limited. Through the seminars of schools and enterprises, both sides reached a cooperation intention and signed international agreements.

\subsection{Set up "Electronic service classes"}

During the period from 2010 July to August, teachers in the department of information management and electronic commerce decided to form "Electronic service classes" after extensive investigation and research. To make sure the graduates could work in E-business service outsourcing or IT service outsourcing, the experimental class students were chosen in the profession of information management and electronic commerce. They don't plan to go to graduate study, and also they are interested in the service outsourcing. Furthermore, they are professional and good at teamwork. First of all, through the research of enterprise experts and teachers, we established the electronic service class curriculum system. Secondly, teaching staff are determined. Finally, the management system and operation mechanism of the experimental class is determined. There are 28 students in the first batch. Then there are 26 students in the second batch. We have a homeroom teacher and employ engineers from Boyan technology, Shanghai Shangpai, Shanghai Chenniao Company, Bejing Lizhengren. Through training, visiting, learning and exercitation, nearly 20 students joined the famous outsourcing enterprises.

\section{SERVICE OUTSOURCING TALENTS TRAINING MECHANISMS OF SCHOOL- ENTERPRISE COOPERATION}

Beijing Union University (BUU), who is focusing on service outsourcing talents training, proposes a complete set of methods. The methods are including specific content, form, impact assessment methods of school-enterprise cooperation.

\subsection{Ideas of service outsourcing talent training mechanism}

First of all, BUU highlights school characteristics for social needs and service outsourcing industry demands. Taking service outsourcing related disciplines as the main line, relying on profession of information management and e-commerce in college of management, BUU re-establishes the reform programs, and provides manpower and intellectual support for the Beijing service outsourcing industry and the companies. It also brings the students into the service outsourcing enterprises to do some related job, which makes they get more standardized training.

Second, BUU follows the professional knowledge system, improves service outsourcing curriculum. On content of teaching, BUU does some crosses with other disciplines. On the professional building, 
BUU tracks the most advanced technology of domestic and international service outsourcing technology. Then the advanced course modules of well-known companies or training institutions are embedded in the curriculum system to ensure adequate internal and external training courses and practice time. These methods could strengthen practical ability, practical language skills and overall quality.
Third, BUU strengthening the outsourcing of professional teachers, enhance teacher corporate experience.

\subsection{The principles and nature of cooperation}

There are five principles of school-enterprise cooperation involved in education, interest, division of labor, government and so on[4]. They are shown in Table 2.

Table 2. The principles and nature of cooperation

\begin{tabular}{|c|l|l|l|}
\hline No. & Principles & Nature & Path \\
\hline 1 & $\begin{array}{l}\text { Education and } \\
\text { training }\end{array}$ & $\begin{array}{l}\text { It is not only an educational behavior, but } \\
\text { also a corporate human resource } \\
\text { development activity. }\end{array}$ & $\begin{array}{l}\text { The main content should be trained to work in the } \\
\text { enterprise. }\end{array}$ \\
\hline 2 & $\begin{array}{l}\text { Equality and mutual } \\
\text { benefit }\end{array}$ & It is a commercial activity. & $\begin{array}{l}\text { To ensure the healthy development of bilateral relations } \\
\text { and cooperation, we should discuss the operation of } \\
\text { projects in accordance with the way of market, rules, } \\
\text { clear responsibilities and rights of both parties }\end{array}$ \\
\hline 3 & $\begin{array}{l}\text { Specialized division } \\
\text { of labor and social } \\
\text { service }\end{array}$ & $\begin{array}{l}\text { It is a social activities which designs large- } \\
\text { scale, high-cost different social subjects of } \\
\text { leading }\end{array}$ & $\begin{array}{l}\text { It relies on community service to be completed. } \\
\text { social and economic community. }\end{array}$ \\
\hline 5 & $\begin{array}{l}\text { Balancing interests } \\
\text { of stakeholders }\end{array}$ & $\begin{array}{l}\text { Its main enterprises involved company } \\
\text { (industry), students and school, and suitable } \\
\text { for non- entirely executive and market. }\end{array}$ & $\begin{array}{l}\text { It needs to take into account the interests of diversity in } \\
\text { public policy. }\end{array}$ \\
\hline
\end{tabular}

\subsection{Power and control mechanism}

Since school-enterprise cooperation is a commercial activity, its subjective concept is different from other activities, and thus also in the interests. To achieve the different interests of students, school and enterprise, it is very important to apply some of the power and control mechanism in school-enterprise cooperation, so that it can ensure there is long-term steady development that both schools and enterprise[5]s. As shown in Table 3.

Table 3. Power and control mechanism of school-enterprise cooperation

\begin{tabular}{|c|c|c|}
\hline No. & $\begin{array}{l}\text { Power and control } \\
\text { mechanism }\end{array}$ & Explain \\
\hline 1 & $\begin{array}{l}\text { The main difference } \\
\text { between the concepts } \\
\text { and benefits }\end{array}$ & $\begin{array}{l}\text { Schools and parents want the basics a little more, put off some professional specialized } \\
\text { training or a little less than basics; while businesses often want less theory, more practice. }\end{array}$ \\
\hline 2 & Position of school & $\begin{array}{l}\text { Understanding of the law on education, we should respect the truth and practice of business, in } \\
\text { teaching content. In practice sessions to enterprises and schools are assisted. On the practical } \\
\text { aspects of school-based, enterprises auxiliary. Strengthening education management to enable } \\
\text { students to pay attention to practice and ensure professional-related, technical content and the } \\
\text { necessary job rotation. Furthermore, the students should avoid to become cheap labor. }\end{array}$ \\
\hline 3 & $\begin{array}{l}\text { Guidance and incentive } \\
\text { mechanism }\end{array}$ & Government should be targeted and effective for incentive mechanism to guide cooperation. \\
\hline 4 & Adjustment mechanism & $\begin{array}{l}\text { There are so many modes of cooperative training, because of the different industries of } \\
\text { services outsourcing talents training. }\end{array}$ \\
\hline 5 & $\begin{array}{l}\text { Mechanism of social } \\
\text { service }\end{array}$ & $\begin{array}{l}\text { Third-party supervision should supervision, coordination and service the contract between } \\
\text { schools and businesses. }\end{array}$ \\
\hline
\end{tabular}

\subsection{Content of training mechanism construction}

Through combining construction ideas and facing the problems[6], the construction of training mechanism includes the following aspects:

(1) Training plan

We establish service outsourcing training through discussing together.
(2) Teachers

Signed business and professional services pick teachers according to the courses and the projects will be carried out or may be carried out. School teachers go to business to practice and business teachers go to school to do some research on related 
projects. They all offer appointment to each other and unified management.

(3) Courses

They both discuss and establish course content together on a special ability and skill. They formulate assessment methods and how to assess together. Through tripartite participation, that is students, teachers and corporate staff, tripartite assess a course common basis for the completion of a certain weight distribution.

(4) Students to develop

For each student, we assign a business mentor and a professional instructor who participate learning course content, practice enterprises, identification assessment of the project and so on.

\subsection{Service outsourcing talents construction chart of the school-enterprise cooperation train}

Through cooperation, we complete a service outsourcing talents construction chart of the schoolenterprise cooperation train. As shown in Figure 1.

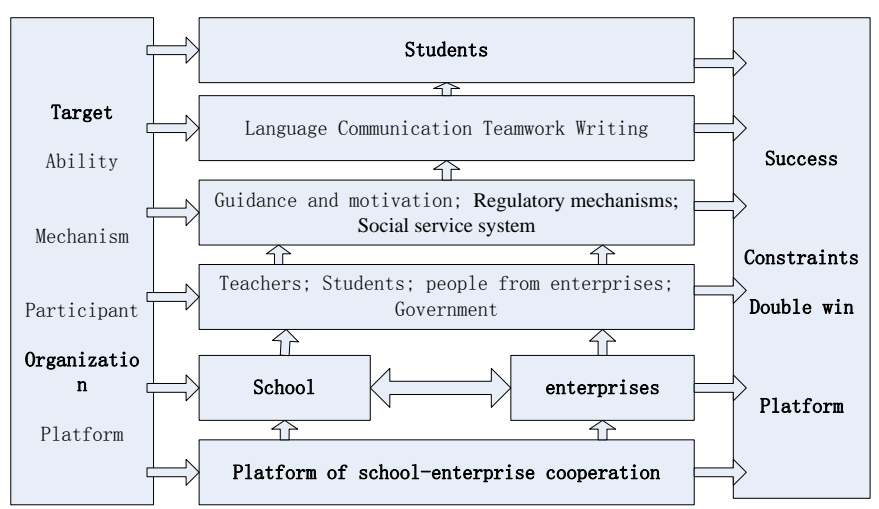

Figure 1. service outsourcing talents construction chart of the Conclusions

School-enterprise cooperation is very important for realistic work of talents training. We must strive to establish long-term mechanism of school-enterprise cooperation. We must clear responsibility of government for school-enterprise cooperation. We must standardize the management of schoolenterprise cooperation and establish the standard school-enterprise cooperation agreement text. We must set up a "practice management committee" to resolve conflicts and problems, in order to balance the interests of all parties. We must speed up infrastructure construction of school-enterprise cooperation, and support, funding internal and external training base. Only the last content is completed, the school-enterprise cooperation will be truly reality.

\section{ACKNOWLEDGEMENT}

This paper is supported by the Project of Education Research and Reform in Beijing Union University " Research and Practice of Composite Application Personnel Training school-enterprise cooperation Base Group Construction (No.11103581106). And "National innovation pilot area of service outsourcing talents training model" (No.12205994711).

\section{REFERENCES}

[1] Youe Cheng. Study and practice based on IT outsourcing cloud platform of education reform based training model. The Chinese Journal of ICT in Education, 2013(8).10-12.

[2] National long-term Education Reform and Development Plan (2010 -2020), http://www.gov.cn/jrzg/201007/29/content_1667143.htm

[3] Yingyan Wang. Industry-university collaborative governance with innovative logistics service outsourcing talent training mode. Modern Enterprise Education, 2013, (3). 172-173.

[4] Hongbiao Xie. Exploration and practice of software service outsourcing talent training mode. China Science and Technology Information, 2009, (24), 29-33.

[5] Wei Zhang, Zhi Chen. Exploration of school-enterprises service outsourcing talents training mechanism in Nanjing University of Posts and Telecommunication. Science and Technology Information, 2012, (34). 4-5.

[6] Zuguang $\mathrm{Yu}$. Research on mechanisms of vocational education in school-enterprise cooperation. Chinese Vocational and Technical Education, 2009, (332).5-11.

\section{ABOUT AUTHORS}

Wanxin Xue (1966.5) and Yilei Pei (1982.12) are from Liaoning province, Dandan Li (1982.08) is corresponding author, and she is from Heilongjiang province. They all work in Beijing Union University. Their research directions are E-commerce and Internet Marketing.

E-mail:xuewanxin@126.com, peiyilei@126.com, gltdandan@buu.edu.cn 